\title{
Effect of Slanted Soil Design and Filter Media Distribution on the Removal of Fecal Bacteria and Organic Matter from Greywater
}

\author{
Ynoussa Maiga $^{1 *}$, Awa Ndiaye ${ }^{2}$, Drissa Sangaré ${ }^{3}$, Emeline Bitié $^{4}$ and Ken Ushijima ${ }^{5}$ \\ ${ }^{1}$ University Ouaga 1 Pr Joseph KI-ZERBO, Laboratory of Microbiology and Microbial \\ Biotechnology, 03 BP 7021 Ouagadougou 03, Ouagadougou, Burkina Faso \\ ${ }^{2}$ Biological Sciences, Peleforo Gon Coulibaly University, BP 1328 Korhogo, Côte d'Ivoire \\ ${ }^{3}$ University of Man, BP 20 Man, Côte d'Ivoire \\ ${ }^{4}$ International Institute for Water and Environmental Engineering, 01 BP 594 Ouagadougou \\ 01, Ouagadougou Burkina Faso \\ ${ }^{5}$ Environmental Engineering and Science, Hokkaido University, kital3-nishi 8, Kita-ku, \\ Sapporo-shi, Hokkaido 060-8628, Japan
}

*Corresponding author

\begin{abstract}
A B S T R A C T
Slanted Soil Treatment System (SSTS) was previously designed for onsite greywater

\section{Keywords}

Granit, Greywater, Indicator bacteria, Slanted soil system

Article Info

Accepted:

17 June 2018

Available Online:

10 July 2018

treatment. In this study, several configurations were tested with granitic gravel in order to improve its efficiency. The lowest average removal efficiencies for fecal coliforms, enterococci and $E$. coli were 1.78, 2.15 and $2.21 \mathrm{log}$ u. respectively and originated from case 3 (length $3 \mathrm{~m}$, width $20 \mathrm{~cm}$, grain size in second box 1-4 mm). The highest removal efficiencies originated from case 1 (length $5 \mathrm{~m}$, width $20 \mathrm{~cm}$, grain size in second box 1-2 $\mathrm{mm}$ ) with values of 2.66, 2.56 and $2.51 \log \mathrm{u}$. for fecal coliforms, enterococci and $E$. coli respectively. The average removal of suspended solids varied from $62 \%$ (case 3 ) to $92 \%$ (case 1). The comparison of the performances highlighted that the removal of indicator bacteria was more affected by the variations in the characteristics of the SSTS than that of organic matter. Based on these results, a SSTS with a length of $5 \mathrm{~m}$, a width of $30 \mathrm{~cm}$ and a grain size of 1-4 mm (to avoid early clogging) is suggested in order to enhance the removal of indicator bacteria. However, for organic matter, further studies are necessary to improve the removal efficiency.
\end{abstract}

\section{Introduction}

In 2015, it was estimated that 2.4 billion people globally still lack improved sanitation facilities and that the least developed countries did not meet the sanitation target. The use of improved sanitation facilities is particularly low in Sub-Saharan Africa (30\% overall) and despite this, the disparity between urban and rural areas is striking. Indeed, seven out of ten people without improved sanitation facilities live globally in rural areas (WHO-UNICEF, 2015). 
In addition, arid regions throughout the world are facing increasing water scarcity because of climate change and population increase (Wu et al., 2013). Water scarcity is responsible of food shortage in developing countries particularly in Sahelian regions. For continuous food production, adequate longterm water supplies are necessary for agricultural irrigation.

Wastewater treatment for reuse in irrigation is an environment friendly solution to tackle water shortage and sanitation problems in developing countries. Greywater accounts for up to $75 \%$ of the wastewater produced in a household (Hernandez-Leal et al., 2011). In arid regions, it can be reused for many purposes such as gardening because there is no mixing with black water. However, one of the major obstacles to this type of reuse is the possible presence of pathogenic microorganisms and chemical parameters (Finley et al., 2009). Therefore, it is imperative to design onsite treatment systems for greywater treatment before reuse. In this order, Maiga et al., (2014) have designed a greywater treatment unit (slanted soil system) for rural and peri-urban communities. This greywater treatment unit was able to collect and treat greywater from various sources at household level. It was connected to the shower room allowing the direct collection of shower greywater; it also allowed the collection of kitchen and laundry greywater. However, it exhibited low bacterial and suspended solids removal because of the coarse gravel (1-9 $\mathrm{mm})$ used to fill the boxes.

The major issue in greywater treatment by slanted soil system is how to join high efficiency and longer clogging time. Ushijima et al., (2013) showed that coarser particles can provide longer clogging time but low microbial removal while fine particles can provide good efficiency but shorter clogging time. Therefore, in this study, combinations of coarse and fine soils were used, with the aim of determining the influence of the design characteristics of the SSTS on the improvement of fecal indicators and organic matter removal from greywater.

The specific objectives were to: (i) evaluate the efficiency of SSTS on indicator bacteria and organic matter removal, (ii) evaluate the effect of granitic filter characteristics (length, width) on indicator bacteria and organic matter removal and (iii) evaluate the influence of granitic grain size on the removal of microbial and physico-chemical parameters from greywater.

\section{Materials and Methods}

\section{Experimental design}

The experimental setup was located in a pilot scale waste stabilization pond at Ouagadougou $\left(12^{\circ} \mathrm{N}, 2.3 \mathrm{~W}\right)$ in Burkina Faso, where more than 300 days per year are expected to be sunny. All experiments were carried out on a batch-scale outdoor experimental treatment unit composed of two (2) types of Slanted Soil Treatment System (SSTS) (Figure 1): a short SSTS and a long SSTS, both, made of concrete and plastic boxes. The short SSTS was composed of a cylindrical receiving tank followed by 2 boxes (upper and $2^{\text {nd }}$ box), while the long SSTS was composed of a receiving tank and 3 boxes (upper, $2^{\text {nd }}$ and $3^{\text {rd }}$ box). One half of a plastic cylindrical container $(0.6 \mathrm{mx} 1 \mathrm{~m}$, internal size $)$ was used as the upper box (internal length of $1 \mathrm{~m}$, upper width of $0.6 \mathrm{~m}$ ). The $2^{\text {nd }}$ and $3^{\text {rd }}$ boxes were made of concrete, with internal lengths of $2 \mathrm{~m}$ and varying widths (Table 1).

The receiving tanks were disposed vertically while the boxes were set out slightly horizontally (slope of 2\%) to allow the water flow by gravity. The four SSTS was filled with granitic gravel of different grain size 
(Table 1). Before filling the boxes and the receiving tanks, the granular medium was washed with tap water. The heights of the filter beds were $35 \mathrm{~cm}$ in the vertical receiving tanks and $15 \mathrm{~cm}$ in the $2^{\text {nd }}$ and $3^{\text {rd }}$ boxes. In the upper boxes (derived from the cylindrical container), only the central parts have filter columns of $15 \mathrm{~cm}$, the heights lowering from the centers to the external sides of the boxes.

\section{Greywater collection and pilots feeding}

The experimental SSTS were fed daily with raw greywater (mixed laundry-dishwashing greywater) for two months. The greywater was collected from five households located nearby the experimental site and mixed before distribution. The SSTS were fed discontinuously three times daily $(8 \mathrm{~h}, 12 \mathrm{~h}$ and 18h). At each feeding period, 20 liters of greywater were poured in the receiving tank of each SSTS to give a total of 60 liters / SSTS / day. In order to determine the effectiveness of the treatment, greywater samples were collected at the second feeding period (12h) for analyzes. The samples were collected from the entry (raw greywater) and exit (treated greywater) of each SSTS, as well as from the exit of the receiving tank. In case 1 (long SSTS), an additional sample was collected at the exit of the second box (i.e. after $3 \mathrm{~m}$ of treatment) (Figure 1b) to allow comparison with the other cases. Samples collected after 3 $\mathrm{m}$ of treatment in case 1 will be considered as case $1 \mathrm{~s}$.

\section{Analytical methods}

The $\mathrm{pH}$, temperature and conductivity were determined in situ using a multi-parameter WTW 340i. Suspended solids (SS), Chemical Oxygen Demand (COD) and 5-days Biochemical Demand (BOD5) were determined from homogenized samples to assess the removal efficiency of organic parameters. SS were measured by a gravimetric method using glass microfiber filters Whatman (porosity $1.5 \mu \mathrm{m}$ ). All analyses were conducted according to Standard Methods for the Examination of Water and Wastewater (APHA, 1998). The microbiological pollution was assessed using Escherichia coli, fecal coliforms and enterococci as indicator bacteria. The spread plate method was used after an appropriate dilution of the samples in accordance with the procedure in Standard Methods for the Examination of Water and Wastewater (APHA, 1998). Chromocult coliform agar (Merck KGaA 64271, Darmstadt, Germany) was used as the culture medium for both $E$. coli and fecal coliforms while Slanetz and Bartley medium (Biokar Diagnostics, France) was used for enterococci assessment.

\section{Data analysis}

The data were processed using Excel and $\mathrm{R}$ software (3.0.1 version). For all parameters, removal efficiency was performed in Excel using data of influent (untreated greywater) and effluent. The effects of filters width, length and grain size have been evaluated by comparing the different SSTS (Table 1) using $t$-test at $(\alpha=0.05)$.

The effect of the filter length was evaluated by comparing the results obtained from case $1 \mathrm{~s}$ and case 1 , which shared the same width and grain size distribution but differed in the length of the filter beds.

The effect of the width was assessed by comparing (i) case $1 \mathrm{~s}$ and case 2 , both sharing the same length of $3 \mathrm{~m}$, the same grain size distribution and the $2^{\text {nd }}$ box filled with granitic gravel of 1-2 mm size and (ii) case 3 and case 4 (same length and grain size distribution with the filter of the $2^{\text {nd }}$ box composed of granitic gravel of 1-4 mm size).

The effect of the grain size was determined by comparing (i) the removal efficiencies obtained from the SSTS having a $2^{\text {nd }}$ box of 
$20 \mathrm{~cm}$ width filled with granitic gravel of 1-2 $\mathrm{mm}$ (case 1s) and 1-4 $\mathrm{mm}$ (case 3), the other characteristics of the SSTS being uniform in both cases and (ii) the removal efficiencies of case 2 and case 4 , both having a $2^{\text {nd }}$ box of 30 $\mathrm{cm}$ width filled with granitic gravel of 1-2 $\mathrm{mm}$ and 1-4 $\mathrm{mm}$ respectively, the other characteristics of the SSTS being identical.

\section{Results and Discussion}

\section{Greywater characteristics}

The raw greywater used for the treatment exhibited slightly acidic to neutral $\mathrm{pH}$ values (6.19 to 7.45 ) with electrical conductivity ranging from 0.86 to $6.71 \mathrm{mS} \mathrm{cm}$. The greywater were heavily loaded with organic matter (SS, BOD5 and COD) and fecal indicators (E. coli, Fecal coliforms and enterococci) (Table 2). The high organic matter content is due to the origin of the greywater. Previous study has reported that high concentrations in $\mathrm{BOD}_{5}\left(1460 \mathrm{mg} \mathrm{L}^{-1}\right)$ and COD (2950 mg L L $\mathrm{m}^{-1}$ are found in dishwashing and laundry greywater (Li et al., 2009). Besides, Maiga et al., (2014) conducted a study in rural area and showed that mixed laundry-dishwashing greywater $(\mathrm{SS}=1230$ $\mathrm{mg} \mathrm{L}^{-1}, \mathrm{COD}=3916 \mathrm{mg} \mathrm{L}^{-1}$ and $\mathrm{BOD}_{5}=1375$ $\mathrm{mg} \mathrm{\textrm {L } ^ { - 1 }}$ ) were more polluted in terms of organic matter pollution than shower greywater $\left(\mathrm{SS}=690 \mathrm{mg} \mathrm{L}^{-1}, \mathrm{COD}=1263 \mathrm{mg}\right.$ $\mathrm{L}^{-1}$ and $\mathrm{BOD}=625 \mathrm{mg} \mathrm{L}^{-1}$ ). Adugna et al., (2015) have also reported mean values of SS $2250 \mathrm{mg} \mathrm{L}^{-1}, \mathrm{BOD}_{5} 1039 \mathrm{mg} \mathrm{L}^{-1}$ and COD $2225 \mathrm{mg} \mathrm{L}^{-1}$ for greywater collected in urban poor households in Ouagadougou. The result obtained in this study confirm the high level of organic matter in greywater collected in urban households in Ouagadougou and the need to reduce their concentration before considering any reuse option. The presence of high levels of fecal indicators could be attributed to the presence of babies in the households. The transit of the greywater through the filter media has an impact on the $\mathrm{pH}$ since it leads to an increase in its values after the treatment, whatever the SSTS. Indeed, the mean $\mathrm{pH}$ of 6.76 in the raw greywater increased to values varying from neutral to slightly alkaline in the treated greywater. Granite powder has acid neutralizing capacity (Barral Silva et al., 2005). As greywater passes through the filter media, the natural alkalinity of the filter raises the $\mathrm{pH}$. This increase can be considered as advantageous in the case of greywater reuse in irrigation, as it can promote soil bacterial growth, which is beneficial to vegetables through the provision of nutrients from organic matter. Indeed, Mara (2004) has indicated that most bacteria prefer neutral or slightly alkaline conditions 6.5 to 8.5 . The high temperatures observed in the treated greywater compared to the raw greywater could be related to the influence of the sunlight, the experiments being conducted outdoor. For all the SSTS used, the treatment resulted in a decrease in the organic and microbial contents. However, these loads varied depending on the type of SSTS used for the treatment. The lowest fecal indicator and organic parameters contents were obtained from the case 1 experiments while the highest contents of these parameters were noticed in case 3 (Table 2). These discrepancies observed could be explained by the differences in the treatment capacity of the types of SSTS configurations and the characteristics of the filter beds.

\section{Treatment efficiency}

Different removal efficiencies were noticed for organic parameters (SS, COD and BOD5) as well as fecal indicators (E. coli, fecal coliforms and enterococci), depending on the type of SSTS and filter media distribution (Figure 2).

For both parameters, case 1 exhibited the highest removal efficiencies followed by case 
2 , case $1 \mathrm{~s}$, then case 4 and finally case 3 . Indeed, the average removal efficiencies ranged from $62 \%$ (case 3 ) to $92 \%$ (case 1) for $\mathrm{SS}$, from $26 \%$ (case 3) to $68 \%$ (case 1) for COD and from $62 \%$ (case 3 ) to $94 \%$ (case 1) for BOD5. The removal efficiency of the organic matter was higher than $50 \%$ for SS and BOD5, regardless of the features of the treatment unit and the grain size used. Except in case 1, COD removal was lower than $50 \%$. Globally SS and BOD5 removal were higher than COD removal. Similar trends of $91.2 \%$, $72.5 \%$ and $69.9 \%$ for $\mathrm{SS}, \mathrm{BOD}_{5}$ and $\mathrm{COD}$ respectively, were reported by Prasad et al., (2006) with sand intermittent filtration. Furthermore, Nnaji et al., (2013) pointed out removal efficiency of $83.6 \%$ for $\mathrm{BOD}_{5}$ versus $57.2 \%$ for COD after greywater passed through a filtration unit. Assayed et al., (2014) also reported efficiencies of 97\%, $94 \%$ and $97 \%$ for $\mathrm{BOD}_{5}, \mathrm{COD}$ and $\mathrm{SS}$ respectively, after passage of synthetic greywater in a series of three drawers filled with gravel and silica and operated as a vertical filter. From lab scale experiment, using synthetic greywater, Ushijima et al., (2015) reported removal efficiency of COD varying from 61 to $82 \%$. In our study, greywater was characterized by high level of organic matter which was very variable depending on the activities undertaken in the households; the variability of removal efficiency may be attributed to the fluctuating greywater quality. It can also be related to the different filter beds and the configuration of the SSTS with different removal capabilities.

The weakest removal efficiencies of bacterial indicators originated from case 3 and were $1.78,2.15$ and $2.21 \log \mathrm{u}$. for fecal coliforms, enterococci and $E$. coli respectively. The highest removal efficiencies originated from case 1 and were 2.66, 2.56 and 2.51 $\log \mathrm{u}$. for fecal coliforms, enterococci and $E$. coli respectively (Figure 2). For all the SSTS tested, the mean removal efficiencies of $E$. coli and enterococci, due to their passage through the granitic filters, were higher that 2 $\log$ u. A $3 \log$ u. reduction of $E$. coli has been obtained using drawers operating as a vertical filter (Assayed et al., 2014). Important factors expected to influence indicators bacteria removal from a filter bed include mechanical filtration, temperature and adsorption to organic matter and adhesion to biofilm (Maiga et al., 2017). For example, an average attachment of $8 \times 10^{6}$ bacteria cells per gram of sand was notified by Wand et al., (2007) in their study using a column simulating a vertical flow constructed wetland. Biofilm growth and solid build up on the upper layer of the filter media was also suspected to contribute into bacterial removal by decreasing the free pore spaces which contributes to increase the capability of staining and trapping the bacteria (Vafai, 2011). The removal of pathogens in a filtration unit also depends on the characteristics of the filter bed (nature of filter media). When sand and peat filters were tested during winter season, it appeared that sand filters removed greater than $1 \log \mathrm{u}$. of Salmonella, while the peat filters were responsible for a greater than $5 \log$ u. loss of Salmonella (Pundsack et al., 2001). Furthermore, constructed wetlands are known to harbor diverse protozoa (Vymazal et al., 2001) that can be important predators in the removal of bacteria (Wand et al., 2007). A study has estimated the grazing rates in a gravel media to a value of 49 bacteria / ciliatehour (Decamp et al., 1999). Temperature has been shown to play an important role in the reduction of enteric bacteria from subsurface wetlands. For example, increased temperature will increase the predator activity of grazing protozoa.

\section{Influence of the pilots configurations on the treatment efficiency}

As mentioned above, for both organic and indicator parameters, case 1 exhibited the highest removal efficiency followed by case 2 , case $1 \mathrm{~s}$, then, case 4 and finally case 3 . 
Indeed, for $E$. coli, the removal efficiency ranged from 2.10 to $2.41 \log \mathrm{u}$. in case 3 to the range of 2.32 to $2.67 \log \mathrm{u}$. in case 1 (Figure 3 ). For organic parameters, the removal of COD for example ranged from 7.81 to $63.09 \%$ in case 3 to the range of 79.60 to $93.55 \%$ in case 1 . In order to compare the effect of the pilots configurations on the treatment efficiencies, statistical analyses have been performed.

The comparison of the results obtained from case $1 \mathrm{~s}$ and case 2 highlighted that the variation of the width of the $2^{\text {nd }}$ box from 20 to $30 \mathrm{~cm}$, had a significant effect on the removal efficiency of the SSTS. The removal efficiency was significantly higher in a SSTS having a $2^{\text {nd }}$ box of $30 \mathrm{~cm}$ width than a one with $20 \mathrm{~cm}$ width, both filled with granitic materials of $1-2 \mathrm{~mm}$ size. Indeed, the removal efficiency was significantly higher in case 2 (width of $30 \mathrm{~cm}$ ) compared to case $1 \mathrm{~s}$ (width of $20 \mathrm{~cm}$ ) for $E$. coli $(\mathrm{p}=0.045)$ and when the removal of all indicators were considered $(p=0.025)$. The same result was obtained while filling the second box with granitic particles of $1-4 \mathrm{~mm}$ size (case 3 and case 4) when the removal of all indicators were considered $(p=0.001)$. However, there was no significant difference in terms of organic pollution removal when SSTS having a second box of 20 and $30 \mathrm{~cm}$ width were compared whatever the grain size considered $(\mathrm{p}=0.05$ for $1-2 \mathrm{~mm} ; \mathrm{p}=0.29$ for $1-4 \mathrm{~mm})$.

Adsorption to filter media is one of the mechanisms involved in bacteria removal from aqueous suspensions (Kwon et al., 2013). Studies have shown the possibility of adsorbing Gram-positive and Gram-negative bacteria to minerals such as quartz and corundum (Yee et al., 2000; Rong et al., 2008). Bacterial surfaces possesse acidic and basic functional groups that are known to be associated with peptidoglycan, teichoic acid (in the case of Gram-positive bacteria) or lipopolysaccharides, phospholipids (in the case of Gram negative bacteria). The presence of these functional groups influence the electrostatic behavior of the cells, thus regulating the bacterial adhesion (Chen and Walker 2007; Yongsuk and Brown 2008). The increase in width offers more space for the adsorption of bacteria to the filter bed particles that can explain the significant difference noticed between the filters of 30 and $20 \mathrm{~cm}$ widths in terms of indicator bacteria removal.

To evaluate the effect of filter length on treatment efficiency, the results obtained in case 1 (long SSTS) were compared with those obtained in case $1 \mathrm{~s}$ (short SSTS), the SSTS differing only at the length of the filter beds. With the configuration considered in Table 1, it appeared that long SSTS (length of $5 \mathrm{~m}$ ) was significantly efficient compared to short SSTS (length of $3 \mathrm{~m}$ ) in terms of (i) the elimination of E. coli $\left(\mathrm{p}=2.3 \times 10^{-4}\right)$, (ii) when the removal of all indicators were considered $\left(\mathrm{p}=4.14 \times 10^{-6}\right)$ and (iii) for the removal of whole organic parameters $\left(p=7.4 \times 10^{-3}\right)$. Mechanical filtration and adsorption being some of the mechanisms involved in bacteria removal from a filter bed, the raise in its length will amplify the availability of adsorption sites that will increase the quantity of bacteria trapped and then, enhance the efficiency. Indeed, as previously mentioned, both Gram-positive and Gram-negative bacteria can be adsorbed to quartz minerals (Yee et al., 2000; Rong et al., 2008).

The effect of grain size on the elimination of microbial and organic parameters was determined by comparing SSTS of $3 \mathrm{~m}$ length having a second box filled with granitic particles of varying size: (i) with a $2^{\text {nd }}$ box of $20 \mathrm{~cm}$ width, filled with granitic particles of 1 - $2 \mathrm{~mm}$ (case 1s) and 1 - $4 \mathrm{~mm}$ (case 3), it appeared that case $1 \mathrm{~s}$ was significantly efficient than case 3 regarding the removal of E. $\operatorname{coli}\left(\mathrm{p}=6.9 \times 10^{-3}\right)$ and the whole indicators 
$\left(\mathrm{p}=4.8 \times 10^{-4}\right)$. However, no significant difference between case $1 \mathrm{~s}$ and case 3 appeared when organic parameters were considered ( $\mathrm{p}=0.08)$; (ii) When the width of the $2^{\text {nd }}$ box was increased to $30 \mathrm{~cm}$, the same results were obtained: the efficiency of case 2 (grain size of $1-2 \mathrm{~mm}$ ) was significantly higher than that of case 4 (grain size of $1-4$ $\mathrm{mm})$ in terms of the removal of E. coli ( $\mathrm{p}=$ 0.01 ) and when the removal of whole indicators was considered $\left(p=7.9 \times 10^{-3}\right)$. The removal of microorganisms in a filtration unit depends on the characteristics of the filter bed, like the nature of filter media, the grain size etc. In fact, Pundsack et al., (2001), have reported that wetlands constructed with peat media removed a larger amount of Salmonella than a wetland constructed with sand as the filter media. Further, Ushijima et al., (2013), using a filter bed of fine soil in a horizontal subsurface flow wetland, showed that fine soil could remove $E$. coli and MS2 phage while coarse soil could not remove these microorganisms. Likewise in the case of 20 $\mathrm{cm}$ width with varying grain size, no significant difference has emerged from the comparison of case 2 and case 4 (same width of $30 \mathrm{~cm}$ with varying grain size) regarding organic parameters removal $(\mathrm{p}=0.18)$.

By comparing the effect of filter height on SS removal, Todt et al., (2014) indicated that most of the filtration process took place in the uppermost part of the filter $(15 \mathrm{~cm})$. Considering the configuration of the SSTS used in our study, greywater can easily flow through the entire filter length so that, an increase in filter length will enhance the organic matter removal performance. However, an increase in filter width may not have a positive effect on organic matter removal since greywater can flow without being uniformly distributed through the entire width of the filter.

Table.1 Physical characteristics and the filter media distribution of the SSTS

\begin{tabular}{|c|c|c|c|c|c|c|}
\hline & & Case 1 & Case $1 \mathrm{~s}$ & Case 2 & Case 3 & Case 4 \\
\hline \multirow{6}{*}{ 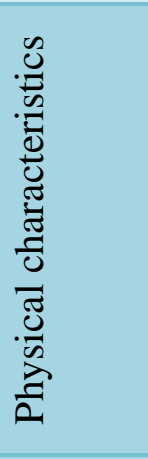 } & Type of SSTS & Long & Short & Short & Short & short \\
\hline & Width $2^{\text {nd }}$ box & $20 \mathrm{~cm}$ & $20 \mathrm{~cm}$ & $30 \mathrm{~cm}$ & $20 \mathrm{~cm}$ & $30 \mathrm{~cm}$ \\
\hline & Width $3^{\text {rd }}$ box & $20 \mathrm{~cm}$ & - & - & - & - \\
\hline & Slope & $2 \%$ & $2 \%$ & $2 \%$ & $2 \%$ & $2 \%$ \\
\hline & Height of filter media & $15 \mathrm{~cm}$ & $15 \mathrm{~cm}$ & $15 \mathrm{~cm}$ & $15 \mathrm{~cm}$ & $15 \mathrm{~cm}$ \\
\hline & $\begin{array}{l}\text { Total length of horizontal } \\
\text { filter }\end{array}$ & $5 \mathrm{~m}$ & $3 \mathrm{~m}$ & $3 \mathrm{~m}$ & $3 \mathrm{~m}$ & $3 \mathrm{~m}$ \\
\hline \multirow{4}{*}{ 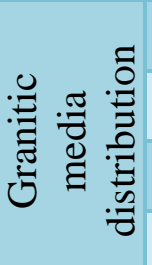 } & Receiving tank & $1-6 \mathrm{~mm}$ & $1-6 \mathrm{~mm}$ & $1-6 \mathrm{~mm}$ & $1-6 \mathrm{~mm}$ & $1-6 \mathrm{~mm}$ \\
\hline & Upper box (1m) & $1-6 \mathrm{~mm}$ & $1-6 \mathrm{~mm}$ & $1-6 \mathrm{~mm}$ & $1-6 \mathrm{~mm}$ & $1-6 \mathrm{~mm}$ \\
\hline & $2^{\text {nd }}$ box $(2 \mathrm{~m})$ & $1-2 \mathrm{~mm}$ & $1-2 \mathrm{~mm}$ & $1-2 \mathrm{~mm}$ & $1-4 \mathrm{~mm}$ & $1-4 \mathrm{~mm}$ \\
\hline & $3^{\text {rd }}$ box $(2 \mathrm{~m})$ & $1-2 \mathrm{~mm}$ & - & - & - & - \\
\hline
\end{tabular}


Table.2 Mean characteristics of raw and treated greywater

\begin{tabular}{|c|c|c|c|c|c|c|c|c|c|}
\hline & & & & \multicolumn{3}{|c|}{ Organic matter $\left(\mathrm{mg} \mathrm{L}^{-1}\right)$} & \multicolumn{3}{|c|}{ Fecal indicators $\left(\mathrm{CFU} 100 \mathrm{~mL}^{-1}\right)$} \\
\hline & pH & $\mathbf{T}^{\circ} \mathbf{C}$ & $\mathrm{EC}\left(\mathrm{mS} \mathrm{cm} \mathrm{cm}^{-1}\right)$ & SS & BOD5 & COD & E. coli & Fecal coliforms & Enterococci \\
\hline Raw greywater & $\begin{array}{c}6.76 \\
(0.47)\end{array}$ & $\begin{array}{l}27.60 \\
(3.58)\end{array}$ & $\begin{array}{c}2.40 \\
(2.15)\end{array}$ & $\begin{array}{l}1751 \\
(964)\end{array}$ & $\begin{array}{l}1275 \\
(275)\end{array}$ & $\begin{array}{l}1546 \\
(205)\end{array}$ & $\begin{array}{c}9.4510^{10} \\
\left(1.11 \times 10^{10}\right)\end{array}$ & $\begin{array}{c}2.23 \times 10^{11} \\
\left(5.01 \times 10^{10}\right)\end{array}$ & $\begin{array}{l}1.31 \times 10^{8} \\
\left(4.8 \times 10^{7}\right)\end{array}$ \\
\hline Treated case 1 & $\begin{array}{c}8.53 \\
(0.69)\end{array}$ & $\begin{array}{l}29.00 \\
(3.65)\end{array}$ & $\begin{array}{c}0.77 \\
(0.54)\end{array}$ & $\begin{array}{c}151 \\
(236)\end{array}$ & $\begin{array}{l}100 \\
(40)\end{array}$ & $\begin{array}{c}500 \\
(539)\end{array}$ & $\begin{array}{c}2.98 \times 10^{8} \\
\left(7.48 \times 10^{7}\right)\end{array}$ & $\begin{array}{c}5.42 \times 10^{8} \\
\left(3.02 \times 10^{8}\right)\end{array}$ & $\begin{array}{r}3.54 \times 10^{5} \\
\left(1.27 \times 10^{5}\right)\end{array}$ \\
\hline Treated case $1 \mathrm{~s}$ & $\begin{array}{c}7.12 \\
(0.25)\end{array}$ & $\begin{array}{l}31.23 \\
(3.40)\end{array}$ & $\begin{array}{c}2.22 \\
(2.16)\end{array}$ & $\begin{array}{c}285 \\
(246)\end{array}$ & $\begin{array}{c}428 \\
(146)\end{array}$ & $\begin{array}{l}1003 \\
(400)\end{array}$ & $\begin{array}{c}4.45 \times 10^{8} \\
\left(9.33 \times 10^{7}\right)\end{array}$ & $\begin{array}{c}8.84 \times 10^{8} \\
\left(4.40 \times 10^{8}\right)\end{array}$ & $\begin{array}{c}6.04 \times 10^{5} \\
\left(2.33 \times 10^{5}\right)\end{array}$ \\
\hline Treated case 2 & $\begin{array}{c}7.54 \\
(0.96)\end{array}$ & $\begin{array}{l}31.23 \\
(4.08)\end{array}$ & $\begin{array}{c}2.21 \\
(2.51)\end{array}$ & $\begin{array}{c}236 \\
(235)\end{array}$ & $\begin{array}{c}400 \\
(221)\end{array}$ & $\begin{array}{c}860 \\
(508)\end{array}$ & $\begin{array}{c}3.75 \times 10^{8} \\
\left(7.46 \times 10^{7}\right)\end{array}$ & $\begin{array}{c}7.41 \times 10^{8} \\
\left(4.45 \times 10^{8}\right)\end{array}$ & $\begin{array}{c}5.49 \times 10^{5} \\
\left(3.16 \times 10^{5}\right)\end{array}$ \\
\hline Treated case 3 & $\begin{array}{c}7.07 \\
(0.36)\end{array}$ & $\begin{array}{l}30.85 \\
(3.98)\end{array}$ & $\begin{array}{c}2.23 \\
(2.50)\end{array}$ & $\begin{array}{c}765 \\
(1012)\end{array}$ & $\begin{array}{c}842 \\
(584)\end{array}$ & $\begin{array}{l}1140 \\
(347)\end{array}$ & $\begin{array}{c}5.99 \times 10^{8} \\
\left(1.15 \times 10^{8}\right)\end{array}$ & $\begin{array}{c}1.07 \times 10^{10} \\
\left(2.03 \times 10^{10}\right)\end{array}$ & $\begin{array}{c}1.94 \times 10^{6} \\
\left(3.72 \times 10^{6}\right)\end{array}$ \\
\hline Treated case 4 & $\begin{array}{c}7.19 \\
(0.41)\end{array}$ & $\begin{array}{l}31.42 \\
(4.89)\end{array}$ & $\begin{array}{c}2.39 \\
(2.80)\end{array}$ & $\begin{array}{c}350 \\
(402)\end{array}$ & $\begin{array}{c}700 \\
(521)\end{array}$ & $\begin{array}{l}1097 \\
(393)\end{array}$ & $\begin{array}{c}5.04 \times 10^{8} \\
\left(1.09 \times 10^{8}\right)\end{array}$ & $\begin{array}{c}8.64 \times 10^{8} \\
\left(4.56 \times 10^{8}\right)\end{array}$ & $\begin{array}{c}6.65 \times 10^{5} \\
\left(2.85 \times 10^{5}\right)\end{array}$ \\
\hline
\end{tabular}

BOD5: Biochemical Oxygen Demand; COD: Chemical oxygen Demand; EC: electrical conductivity; SS: Suspended Solids; T: Temperature. The values in brackets represent the standard deviations. 
a)

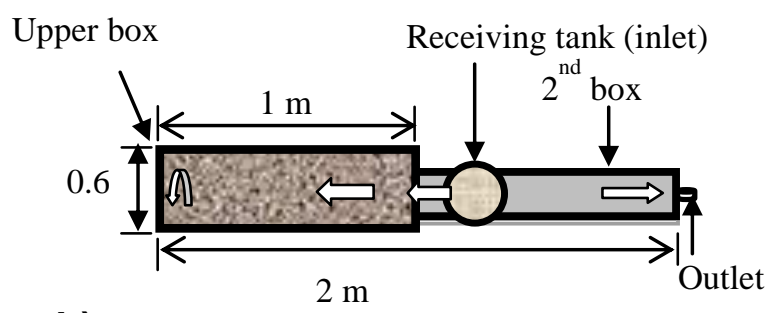

b)

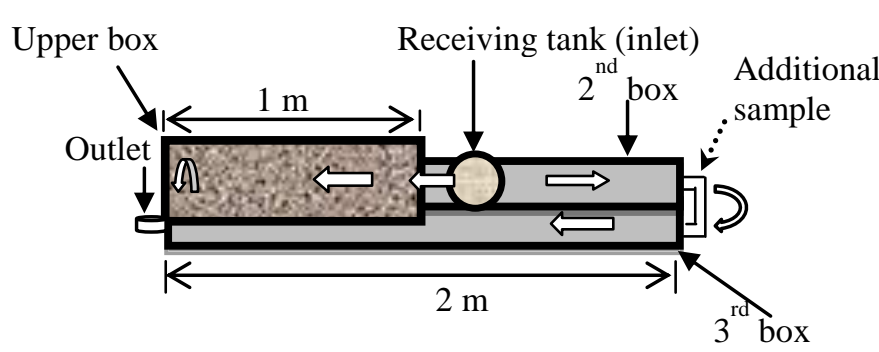

c)

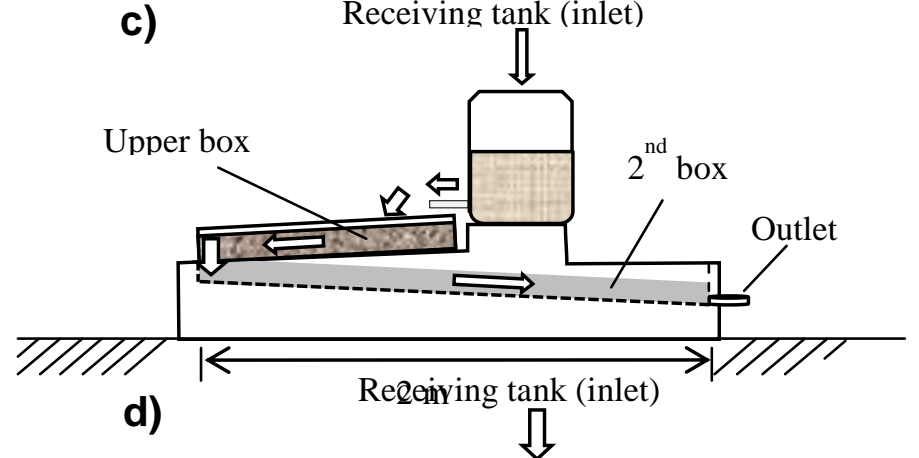

Figure.1 Schematic views of Slanted Soil Treatment System (SSTS): top view of short (a) and long SSTS (b); and side view of short (c) and long SSTS (d) $\Rightarrow$ : indicates water flow direction

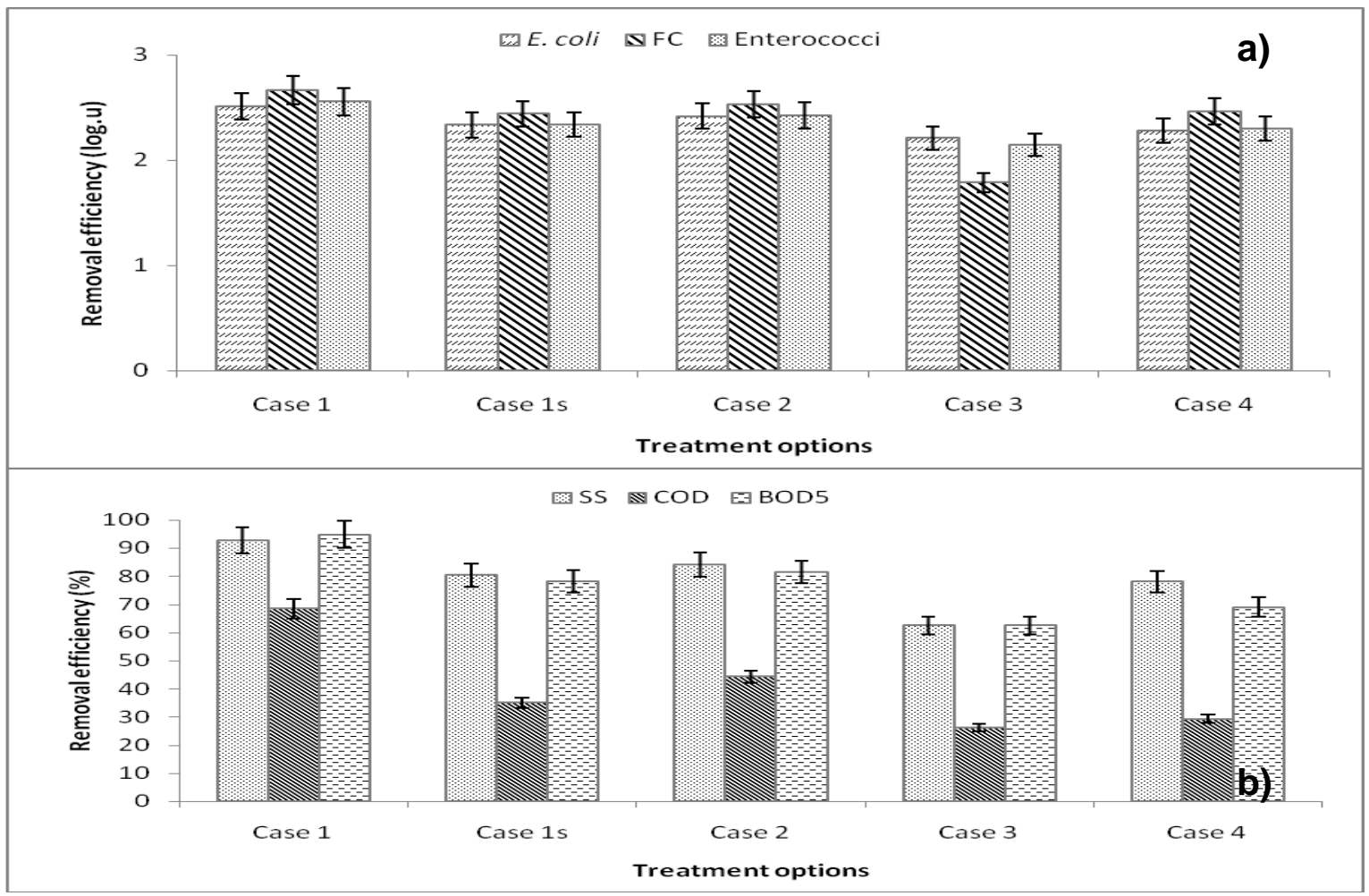

Figure.2 Average removal efficiency of (a) fecal bacteria (E. coli, fecal coliforms, and enterococci), and (b) organic parameters (SS, COD and $\mathrm{BOD}_{5}$ ). BOD5: 5 days Biochemical Oxygen Demand; COD: Chemical oxygen Demand; FC: fecal coliforms; SS: Suspended Solids 

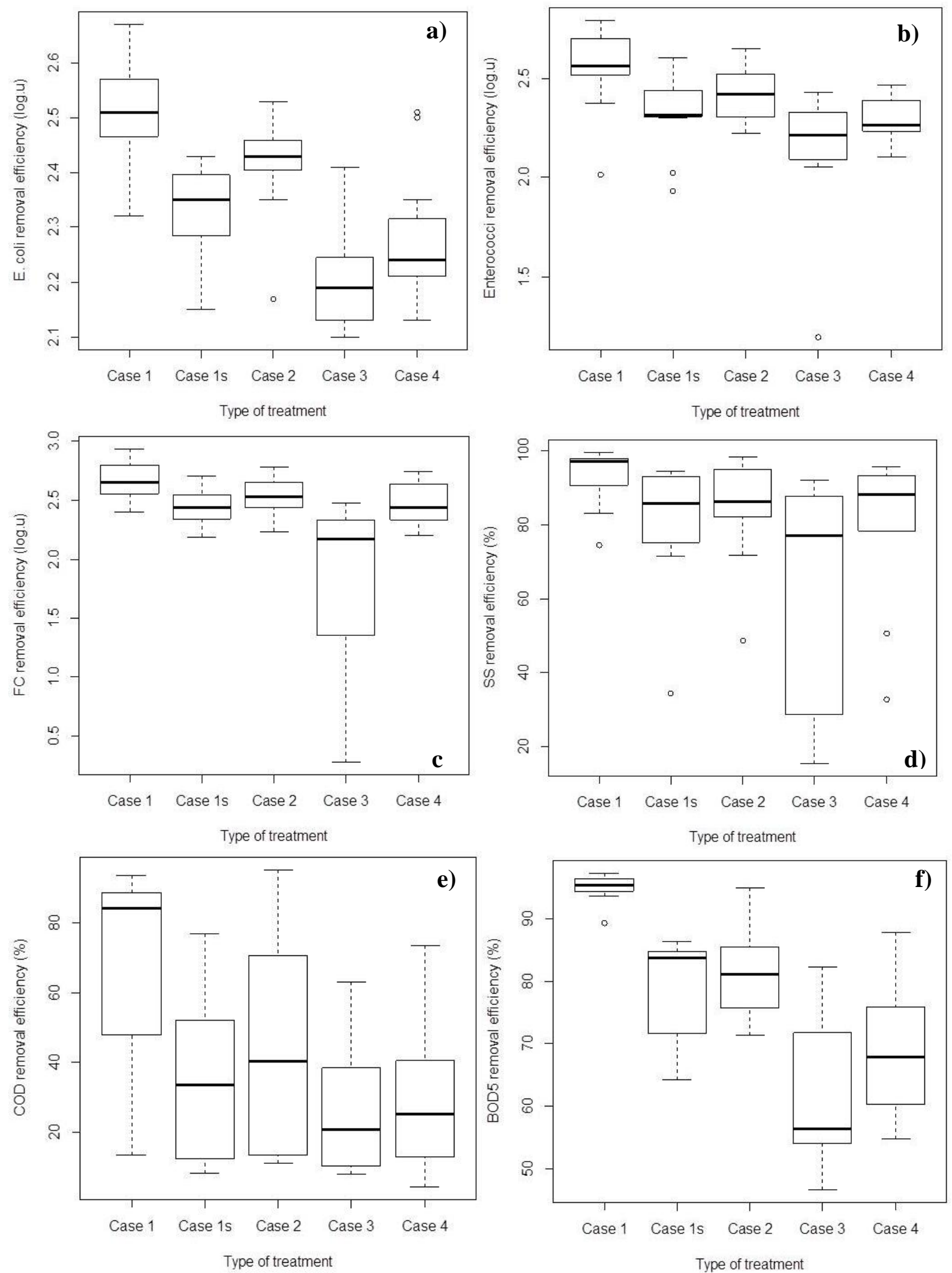

Figure.3 Comparison of different SSTS in terms of microbial and organic pollution removal from greywater. a) E. coli, b) Enterococci, c) Fecal coliforms, d) SS, e) COD and f) BOD5 
In conclusion, this study allowed the comparison of the performances of different configurations of SSTS, previously designed for the treatment of greywater produced in rural and peri-urban households. The results indicated that the physical characteristics and the filter media distribution of the SSTS have influence on the removal of fecal bacteria and organic matter from greywater. For both indicator bacteria and organic parameters, case 1 exhibited the highest removal efficiency with COD and $E$. coli reduction of $79.60-93.55 \%$ and 2.32 - $2.67 \log \mathrm{u}$. respectively, followed by case 2 , case $1 \mathrm{~s}$, then, case 4 and finally case 3 .

The comparison of the different configurations highlighted that indicator bacteria removal was more affected by the modifications than that of organic matter:

(i) The increase of the length from $3 \mathrm{~m}$ to $5 \mathrm{~m}$ enhanced the efficiency in terms of indicator bacteria and organic pollution removal.

(ii) The variation of the width of the $2^{\text {nd }}$ box from 20 to $30 \mathrm{~cm}$, had a significant effect on the removal efficiency of indicator bacteria whatever the grain size (1-2 or 1-4 mm) used in the second box of the SSTS. However, this variation could not significantly improve the removal of organic matter.

(iii) Whatever the width of the second box (20 or $30 \mathrm{~cm}$ ), it appeared that grain size of $1-2$ $\mathrm{mm}$ was significantly more efficient in terms of indicator bacteria removal than grain size of 1-4 mm. No significant difference was noticed for organic matter removal when grain size of 1-2 mm or 1-4 mm was used.

Therefore, in order to enhance the removal performance of the SSTS for indicator bacteria removal, a length of $5 \mathrm{~m}$, a width of $30 \mathrm{~cm}$ and a grain size of 1-4 mm (to avoid early clogging) should be considered. This could be convenient as the designed SSTS is compact and could be connected to the shower room for direct shower greywater collection as well as the collection of laundry and dishwashing greywater through the receiving tank. Further studies are necessary to improve the organic matter removal and to better understand the mechanism of microorganisms' removal in the designed SSTS.

\section{Acknowledgements}

The authors thank Japan International Cooperation Agency (JICA) for providing the funds.

\section{References}

Adugna, A.T., Andriansia, H.A., Konaté, Y., Ndiaye, A., Maiga, A.H. 2015. Performance comparison of sand and fine sawdust vermifilters in treating concentrated greywater for urban poor. Environmental technology, 36(21):2763-2769.

American Public Health Association (APHA), American Water Works Association (AWWA) and Water Environment Federation (WEF). 1998. Standard Methods for the Examination of Water and Wastewater. 20th Edition, APHA/AWWA/WEF, Washington DC.

Assayed, A. Chenoweth, J. and Pedley, S. 2014. Drawer compacted sand filter: a new and innovative method for on-site grey water treatment. Environmental Technology, 35 (17-20): 2435-2446.

Barral Silva, M.T., Silva Hermo, B., GarciaRodeja, E., Vazquez Freire, N. 2005. Reutilization of granite powder as an amendment and fertilizer for acid soils. Chemosphere, 61(7):993-1002.

Chen, G., Walker, S.L. 2007. Role of solution chemistry and ion valence on the 
adhesion kinetics of groundwater and marine bacteria. Langmuir 23(13):7162-7169.

Decamp, O., Warren, A. and Sanchez, R. 1999. The role of ciliated protozoa in subsurface flow wetlands and their potential as bioindicators. Water Science and Technology, 40(3): 9198.

Finley, S., Suzelle Barrington, S. and Lyew, D. 2009. Reuse of domestic greywater for the irrigation of food crops. Water, Air, and Soil Pollution, 199(1-4): 235245.

Hernandez-Leal, L., Temmink, H., Zeeman, G., Buisman, C.J.N. 2011. Characterization and anaerobic biodegradability of grey water. Desalination. 270(1-3):111-115.

Kwon, K.S., Kim, S.B., Choi, N.C., Kim, D.J., Lee, S., Lee, S.H., Choi, J.W. 2013. Deposition and transport of Pseudomonas aeruginosa in porous media: lab scale experiments and model analysis. Environmental Technology, 34(17-20):2757-2764.

Maiga, Y., Moyenga, D., Nikiema, B.C., Ushijima, K., Maiga, A.H and Funamizu, N. 2014. Designing slanted soil system for greywater treatment for irrigation purposes in rural area of arid regions. Environmental Technology, 35(21-24): 3020 - 3027.

Maiga, Y., von Sperling, M., Mihelcic, J. 2017. Constructed Wetlands. In: Global Water Pathogens Project. http://www.waterpathogens.org. (Eds) J.B. Rose and B. Jiménez-Cisneros, Part 4 Management Of Risk from Excreta and Wastewater) http://www.waterpathogens.org/book/ constructed-wetlands. (Eds) (C. Haas, J.R. Mihelcic and M.E.Verbyla). Michigan State University, E. Lansing, MI, UNESCO.

Mara, D. 2004. Domestic wastewater treatment in developing countries. London: Earthscan.

Nnaji, C.C., Mama, C.N., Ekwueme, A. and Utsev, T. 2013. Feasibility of a filtration-adsorption grey water treatment system for developing countries. Hydrology Current Research, S1: 006. doi:10.4172/21577587.S1-006.

Prasad, G., Rajeev, R., Chopra, A.K. 2006. Sand Intermittent Filtration Technology for safer Domestic Sewage Treatment. Journal of Applied Science and Environmental Management, 10(1):73 - 77 .

Pundsack, J., Axler, R., Hicks, R., Henneck, J., Nordman, D. and McCarthy, B. 2001. Seasonal pathogen removal by alternative on-site wastewater systems. Water Environment Research, 73(2): 204-212.

Rong, X., Huang, Q., He, X., Chen, H., Cai, P. and Liang, W. 2008. Interaction of Pseudomonas putida with kaolinite and montmorillonite: a combination study by equilibriul adsorption, ITC, SEM and FTIR. Colloids and Surfaces B : Biointerfaces. 64(1):49-55.

Todt, D., Jenssen, P.D., Klemencic, A.K., A Oarga, and Bulc, T.G. 2014. Removal of particles in organic filters in experimental treatment systems for domestic wastewater and black water. Journal of Environmental Science and Health, Part A, 49(8): 948-954.

Ushijima, K., Ito, K., Ito, R., Funamizu, N. 2013. Greywater treatment by slanted soil system. Ecological Engineering. 50: 62-68.

Ushijima, K., Tanaka, E., Suzuki, L.Y., Hijikata, N., Funamizu, N. and Ito, R. 2015. Greywater treatment by slanted soil system with unsorted soil media. Environmental Technology, 36(20): 2603-2609.

Vafai, K. 2011. Porous media: application in 
biological systems and biotechnology eBook. Bocan Raton (FL): CRC Press, Taylor and Francis.

Vymazal, J., Sládeek, V. and Stach, J. 2001. Biota participating in wastewater treatment in a horizontal flow constructed wetland. Water Science and Technology, 44(11-12): 211-214.

Wand, H., Vacca, G., Kuschk, P., Kruger, M. and Kastner, M. 2007. Removal of bacteria by filtration in planted and non-planted sand columns. Water Research, 41(1): 159-167.

WHO-UNICEF. 2015. Progress on sanitation and drinking water- 2015 update. WHO Press, Geneva, Switzerland

Wu, T.Y., Mohammad, A.W., Lim, S.L., Lim,
P.N., Hay, J.X.W. 2013. Recent Advances in the Reuse of Wastewaters for Promoting Sustainable Development. In: Wastewater Reuse and Management. (Eds.) Sharma S.K. and Sanghi R. Springer. Dordrecht. Pp 47-103.

Yee, N., Fein, J.B. and Daughney, C.J. 2000. Experimental study of the $\mathrm{pH}$, ionic strength, and reversibility behavior of bacteria-mineral adsorption. Geochimica Cosmochimica Acta. 64(4): 609-617.

Yongsuk, H., Brown, D.G. 2008. Electrostatic behavior of the charge-regulated bacterial cell surface. Langmuir 24(9):5003-5009

\section{How to cite this article:}

Ynoussa Maiga, Awa Ndiaye, Drissa Sangaré, Emeline Bitié and Ken Ushijima. 2018. Effect of Slanted Soil Design and Filter Media Distribution on the Removal of Fecal Bacteria and Organic Matter From Greywater Int.J.Curr.Microbiol.App.Sci. 7(07): 2317-2329. doi: https://doi.org/10.20546/ijcmas.2018.707.270 